\title{
Podstawowe problemy przyszłego prawa pracy
}

\author{
Przyszłość należy do tych, \\ którzy przygotowują się do niej dziś.
}

George Orwell

1. Przyszłość prawa pracy zależy od wielu uwarunkowań gospodarczych, społecznych czy nawet politycznych. Pomimo wspólnych cech demokratycznych państw o gospodarce rynkowej, występują w tym zakresie różnice między nimi. Dotyczy to także tradycji i wybieranych dróg rozwoju. Przekładają się one na zróżnicowanie prawa pracy w poszczególnych państwach. Również przyszłość tej dziedziny prawa może kształtować się nieco inaczej w każdym z nich. Stąd też dalsze uwagi odnoszą się do polskich warunków i perspektyw rozwojowych prawa pracy. Nie podważa tego fakt, że pewne cechy prawa pracy są wspólne dla większości państw, do czego przyczynia się także międzynarodowe i unijne prawo pracy. Jak długo będzie obowiązywać, stanowi ono zarazem prawne ramy jego rozwoju w określonych państwach, w tym zwłaszcza państwach członkowskich Unii Europejskiej.

Wiele jest spraw ogólnych i szczegółowych, które zapewne będą wymagały rozwiązania w przyszłości. Dalsze wywody dotyczą tylko kilku z nich, które - jak się wydaje - będą miały kluczowe znaczenia dla przyszłego prawa pracy.

2. Należy założyć, że w przyszłości prawo pracy będzie się nadal opierać na stosunku pracy ${ }^{1}$. Wykształcenie się odrębnego od prawa cywilnego

* Prof. zw. dr hab., Wydział Prawa i Administracji Uniwersytetu Warszawskiego. Kierownik Katedry Prawa Pracy i Polityki Społecznej UW.

${ }^{1}$ Wiele dyrektyw wymienia obydwie podstawy zatrudnienia, co wskazuje na ich zróżnicowanie w poszczególnych państwach członkowskich, na przykład dyrektywa 91/533/EWG w sprawie obowiązku informowania pracowników o warunkach umowy lub stosunku pracy (DzUrz WE L 288 z 08.07.1992). 
stosunku prawnego spowodowane było potrzebą ochrony pracowników jako słabszej strony stosunku pracy. Wynika ona w dużym stopniu z przepisów stanowionych przez państwo, a nie z woli stron. W konsekwencji powstanie stosunku pracy (nawiązanie umowy o pracę) jest równoznaczne z przymusowym zastosowaniem przepisów prawa pracy. Broni się ono bowiem przed ich niestosowaniem. Rozwój prawa pracy polega przede wszystkim na ograniczeniu wykorzystania umowy o pracę. Następuje to od ponad dwóch wieków, w stopniu dużo większym niż w odniesieniu do innych umów prawa prywatnego. Zauważono bowiem, iż swoboda umów i równość ich stron (leżące u podstaw cywilnoprawnego stosunku zobowiązaniowego) w stosunkach pracy były jedynie formalne, a w rzeczywistości pozycja pracodawcy była zdecydowanie silniejsza niż pracownika. Prawo pracy, którego istotny sens sprowadza się do stosunków umownych, z powodu przewagi pracodawcy stawało się coraz bardziej prawem ustawowym ${ }^{2}$. Mając w pamięci nadużywanie swobody umów w okresie wczesnego kapitalizmu, prawo pracy nie ufa umowie ${ }^{3}$, co daje się zauważyć również współcześnie.

Proces ograniczania umowy przez ustawę nie jest jeszcze zakończony, a jego rezultaty nie są jednoznaczne. $Z$ jednej strony, zakres ustawodawstwa pracy wciąż się poszerza. $Z$ drugiej natomiast widoczna jest tendencja do ograniczenia roli ustawy (deregulacja prawa pracy) spowodowana wzrostem konkurencji międzynarodowej i potrzebą zwalczania bezrobocia. Dotyczy to zwłaszcza starych państw Unii, gdzie obserwuje się częściowe wycofywanie się państwa z regulacji warunków zatrudnienia ${ }^{4}$.

Również w przyszłości $\mathrm{w}$ prawie pracy musi dochodzić do ograniczenia swobody umów. W przeciwnym razie pracodawcy kształtowaliby je z naruszeniem pozycji pracowników. Dotyczy to przede wszystkim rodzaju umowy zawieranej z osobą mającą świadczyć pracę na warunkach określonych prawem. $Z$ tego punktu widzenia zatrudnienie spełniające te warunki następuje na podstawie stosunku pracy, bez względu na nazwę zawartej umowy (por. art. $22 \S 1^{1}$ k.p.). Ograniczenie swobody umów musi dotyczyć również treści umowy. W szczególności w przyszłości należy zachować regułę, że nie można odejść od przepisów prawa pracy na niekorzyść pracownika. Reguła ta występuje również w międzynarodowym i unijnym prawie pracy. Bez zachowania tych ograniczeń swobody umów, prawo pracy straciłoby swój ochronny charakter, rozwijany od ponad dwóch wieków.

2 J. Jończyk, Prawo pracy, Warszawa 1995 , s. 133.

3 Por. P. Hanau, K. Adomeit, Arbeitsrecht, Luchterhand 2005, s. 24-25.

${ }^{4}$ Por. np. Beyond Employment. Changes in Work and the Future of Labour Law in Europe, ed. A. Supiot, University Press, Oxford 2001, s. 139, gdzie stwierdza się „What all EU countries appear to have in common at the present time is a general retreat of the State at national level". 
3. Niektórzy przedstawiciele pracodawców, jak również ekonomiści utrzymują że stosunek pracy ma charakter przestarzały, a „etat" nie przystaje do pewnych rodzajów zatrudnienia, na przykład w budownictwie. Szerokie obecnie stosowanie umów cywilnoprawnych rodzi chęć zanegowania zatrudnienia pracowniczego. Trudno zgodzić się z tym poglądem. Jak powyżej wspomniano, stosunek pracy obejmuje przepisy stanowione przez państwo, które mają charakter ochronny. Z reguły nie można od nich odejść na niekorzyść pracowników. Taki też charakter mają postanowienia normatywne aktów prawnych pochodzących od partnerów społecznych. Obok tego stosunek pracy jest kształtowany wolą stron. Pozwala to na określenie w szczególności rodzaju, miejsca, rozmiaru czy długości zatrudnienia, jak i wysokości wynagrodzenia. Obok tego pracodawca ma swobodę kształtowania czasu pracy, a zwłaszcza jego rozkładu ${ }^{5}$. Treść stosunku pracy może być więc dostosowana do bardzo różnorodnych warunków wykonywania pracy. Ochrona wynikająca z przepisów ustawowych nie przekreśla możliwości daleko idącej indywidualizacji warunków zatrudnienia w umowie. Prawo chroni jedynie pracownika przed niekorzystnym jej ukształtowaniem, jak - zwłaszcza - nadmierny czas pracy, ciągłe zatrudnienie na czas określony, jednostronne ustalanie miejsca pracy czy wynagrodzenie niższe niż minimalne.

Prawa pracy nie zastąpi ochrona innych wykonawców pracy, w tym zwłaszcza zatrudnionych na podstawie umów cywilnoprawnych. Ochrona ta byłaby zreszta, jak o tym mowa poniżej, wzorowana na uprawnieniach pracowniczych i pochodna od nich. Odejście od stosunku pracy oznaczałoby, że wykonawcy pracy przestają być pracownikami. Pozbawiałoby to ich szeregu istotnych uprawnień, które przysługują tylko pracownikom, jak chociażby maksymalny czas pracy, urlop wypoczynkowy, ochrona przed zwolnieniem z pracy czy wynagrodzenie minimalne, żeby wymienić tylko najbardziej powszechne.

Prawo międzynarodowe, w tym zwłaszcza konwencje Międzynarodowej Organizacji Pracy oraz prawo unijne, obejmuje ochroną przede wszystkim pracowników, a tylko w niewielkim stopniu pozostałe osoby świadczące pracę na innej podstawie. Również swoboda przepływu w Unii Europejskiej przysługuje przede wszystkim pracownikom, których prawo unijne definiuje jednolicie, w sposób bardzo podobny do naszego prawa. Trudno sobie wyobrazić, że na skutek odejścia od stosunku pracy zniknęłaby u nas kategoria pracowników. Możliwe jest natomiast „unowocześnienie" stosunku pracy, poprzez lepsze dopasowanie go do zróżnicowanego rynku pracy. W szczególności obok podstawowego modelu

${ }^{5}$ Szerzej Ł. Pisarczyk, "Uelastycznienie” czasu pracy jako element przemian stosunku pracy, [w:] Z zagadnień prawa pracy i prawa socjalnego. Ksiega Jubileuszowa Profesora Herberta Szurgacza, Difin, Warszawa 2011, s. 180 oraz 188 i nast. 
stosunku pracy, z którym łączy się rozbudowana ochrona pracy, możliwe byłyby nietypowe stosunki pracy, których treść w większym stopniu mogłoby kształtować ich strony ${ }^{6}$. Dotyczy to zwłaszcza tych grup osób, które mają silniejszą pozycję rynkową. Obecnie przepisy prawa chronią w podobnym stopniu pracowników wykonujących prace proste i poszukiwanych na rynku specjalistów. Uelastycznienie stosunku pracy pozwala dokonać wyboru pomiędzy poszczególnymi elementami ochrony pracowników, przejście na umowy cywilnoprawne całkowicie pozbawiałoby ich ochrony, którą należałoby dopiero budować od nowa.

4. Przymusowy charakter stosunku pracy łączy się ściśle z egzekwowaniem zatrudnienia pracowniczego. Problem ten nie jest do końca rozwiązany. Niewątpliwie na organach państwa powinien ciążyć obowiązek wykrywania i sankcjonowania zatrudnienia mającego wyraźne cechy stosunku pracy, wykonywanego na innej podstawie prawnej, w tym zwłaszcza w oparciu na umowie cywilnoprawnej. Natomiast tolerowanie w przyszłości takiego stanu rzeczy przez dłuższy czas musi prowadzić do obniżenia szacunku dla prawa $\mathrm{w}$ stosunkach pracy. Jest to bowiem najbardziej wyraźny przejaw nieskuteczności stosowania prawa pracy ${ }^{7}$ Często chodzi przy tym o sytuacje oczywiste ${ }^{8}$, kiedy za umową cywilnoprawną kryje się niewątpliwe zatrudnienie pracownicze. Dotyczy to także samozatrudnienia, określanego niekiedy jako fałszywe ${ }^{9}$. Nierzadko takie zatrudnienie jest wymuszane na osobach wcześniej wykonujących daną pracę na podstawie stosunku pracy.

Jeżeli nawet za stosowaniem umów cywilnoprawnych przemawiają pewne racje gospodarcze, $\mathrm{w}$ tym zwłaszcza nadmierne obciążenia $\mathrm{z}$ tytułu zatrudnienia pracowniczego słabych ekonomiczne pracodawców, to należałoby raczej dążyć do obniżenia tych obciążeń. Możliwe byłoby również takie określenie treści stosunku pracy, że będzie on obejmował mniejszy krąg zatrudnionych. Tolerowanie pozornych umów cywilnoprawnych prowadzi do sytuacji, w której powiększa się zakres ich stosowania, co zachodzi zwłaszcza w odniesieniu do osób podejmujących pracę czy mających słabszą pozycję rynkowa, na przykład wykonujących

${ }^{6}$ Por. T. Liszcz, Swoboda umów w prawie pracy, [w:] Wolność i sprawiedliwość w zatrudnieniu. Księga Pamiątkowa poświęcona Prezydentowi Rzeczypospolitej Polskiej Profesorowi Lechowi Kaczyńskiemu, red. M. Seweryński, J. Stelina, Gdańsk 2012, s. 191.

7 M. Seweryński, Uwagi o efektywności prawa pracy, [w:] Księga Pamiątkowa w piata rocznicę śmierci Profesora Andrzeja Kijowskiego, red. Z. Niedbała, Warszawa 2010, s. 275.

8 Tym samym, jak stwierdza A. Kijowski, Zakres swobody pracodawcy w korzystaniu z zatrudnienia cywilnoprawnego, [w:] Prawo pracy a wyzwania XXI wieku. Księga jubileuszowa Profesora Tadeusza Zielińskiego, red. M. Matey-Tyrowicz, L. Nawacki, B. Wagner, Warszawa 2002, s. 221, „z ostrożnością i krytycyzmem” należy podchodzić do nadużywania tego przez organy Zakładu Ubezpieczeń Społecznych i Państwowej Inspekcji Pracy.

${ }^{9}$ M. Seweryński, Uwagi o efektywności prawa pracy..., s. 275. 
prace wymagające niskich kwalifikacji, a tym samym łatwych do zastąpienia przez inne osoby. W krańcowym przypadku może dojść do sytuacji, że umowy o pracę będą mieli tylko ci pracownicy, na których zatrudnieniu zależy pracodawcy.

O ile wykrywanie pozornego zatrudnienia cywilnoprawnego jest zadaniem organów nadzoru nad warunkami pracy (inspekcji pracy), o tyle ustalanie jego charakteru należy do sądów. Problemem wymagającym rozwiązania w przyszłości jest sprzeczność pomiędzy warunkami zatrudnienia a wolą stron. Nawet jeżeli zatrudnienie ma charakter pracowniczy, to niekiedy sądy powołując się na swobodę umów odmawiają jego uznania za stosunek pracy. Rzecz jest dodatkowo złożona przez to, że niekiedy strony nie są tym zainteresowane. Podmiot zatrudniający korzysta na tym poprzez niestosowanie prawa pracy i mniejsze narzuty na pracę. Wykonawca pracy również może odnosić korzyści finansowe, zwłaszcza w postaci wyższego wynagrodzenia. Nierzadko zgadza się też na zatrudnienie mniej korzystne $\mathrm{z}$ obawy, że i tak nie utrzyma zatrudnienia w charakterze pracownika.

5. Nie da się jednoznacznie i wyczerpująco wskazać, jakie elementy treści stosunku pracy powinny mieć charakter minimalny, a przez to gwarantowany pracownikom. Tym samym w przyszłości może dochodzić do zmian w tym zakresie. Poza ochroną życia i zdrowia pracowników państwo może wycofywać się z gwarancji niektórych uprawnień pracowniczych. Wskazuje na to zresztą zróżnicowanie ustawowej ochrony pracowników w poszczególnych krajach. Nie oznacza to, że pracownicy pozbawieni byliby szerszej ochrony, lecz wynikałaby ona z prawa autonomicznego, w tym zwłaszcza z układów zbiorowych pracy. Taki zabieg z reguły ma także pozytywny wpływ na gospodarkę, ze względu na możliwość lepszego dopasowania warunków pracy i płacy w drodze przepisów autonomicznych niż pochodzących od państwa. Wydaje się to również najlepszym sposobem uelastycznienia prawa pracy. Prawo pracy w przyszłości „nie ucieknie” od tego problemu. Rozwój uprawnień pracowniczych i związanych z tym obciążeń pracodawców zmniejsza ich konkurencyjność istotną w warunkach gospodarki globalnej. Prawo zaś pracy musi być zgodne z zasadami gospodarki społeczno-rynkowej, co uzasadnia się także koniecznością sprostania wymaganiom globalnej gospodarki rynkowej ${ }^{10}$. Potrzebę zdynamizowania gospodarki czy przeciwdziałania jej kryzysowi łączy się natomiast zazwyczaj z postulatami uelastycznienia prawa pracy.

Brak jest gotowej recepty na owo uelastycznienie. Doświadczenia innych państw wskazują na duże zróżnicowanie możliwych rozwiązań prawnych. Są to przy tym najczęściej rozwiązania częściowe, a nie kompletny

10 Ibidem, s. 279. 
program obejmujący wszystkie działy prawa pracy. Wynika to nie tylko z różnorodnych warunków, w jakich uelastycznia się prawo pracy, ale też ze zróżnicowanej oceny przyczyn i następstw tego zabiegu. W każdym przypadku należy przy tym zapewnić równowage pomiędzy elastycznością rynku pracy a bezpieczeństwem pracowników (flexicurity $)^{11}$. Obok tego występują inne założenia, na przykład ochrona zdrowia pracowników czy godzenie życia rodzinnego z życiem zawodowym. Niezależnie od zakresu uelastycznienia prawa pracy najtrudniejszą sprawą jest, i to zapewnie nie ulegnie zmianie $\mathrm{w}$ przyszłości, negatywne nastawienie do tego pracowników, a zwłaszcza reprezentujących je związków zawodowych. Z tej również przyczyny łatwiej byłoby dokonywać tego w układach zbiorowych pracy niż w ustawodawstwie pracy. Układ jest bowiem kompromisem osiąganym wspólnie przez pracodawcę i związki zawodowe, na podstawie którego każda ze stron może coś zyskać. Pracodawcy i związki zawodowe nie muszą też - tak jak partie polityczne - obawiać się negatywnych następstw politycznych określonych zmian w prawie pracy. W każdym przypadku jednak warunkiem racjonalnych zmian $\mathrm{w}$ prawie pracy musi być partnerstwo pracy i kapitału oraz społecznie odpowiedzialne postawy obydwu stron ${ }^{12}$. Wymaga to także poszerzenia swobody układowej (obecnie zbliżonej do indywidualnej swobody umów). W szczególności należy 270 w szerszym zakresie dopuścić możliwość zastępowania przepisów ustawowych postanowieniami układów zbiorowych pracy ${ }^{13}$.

Szczególnym przejawem uelastycznienia prawa pracy będzie na pewno w przyszłości rozwój atypowych form zatrudnienia. Najlepszym przykładem jest tu praca tymczasowa, która uwalnia pracodawcę od części obowiązków związanych z zatrudnieniem pracownika lub innego wykonawcy pracy, zapewniając zarazem świadczenie pracy przez potrzebny czas. W przyszłości obok telepracy można się spodziewać dalszych form pracy atypowej związanych z technologiami internetowymi. Dosyć oczywiste są natomiast takie formy zatrudnienia, które ograniczają jego rozmiar lub czas trwania. To ostatnie nie może być stosowane w nieograniczonym zakresie, gdyż jest zarazem ucieczką od korzyści, jakie pracownikowi daje umowa na czas nieokreślony.

6. Przyszłość prawa pracy wymaga niewątpliwie uregulowania zatrudnienia na podstawie umów cywilnoprawnych. Przepisy kodeksu cywilnego dotyczące umowy zlecenia, umowy o dzieło czy umowy o świad-

${ }^{11}$ Por. np. M. Rycak, Wptyw koncepcji flexicurity na przemiany stosunku pracy, [w:] Wspótczesne problemy prawa pracy i ubezpieczeń społecznych, red. L. Florek, Ł. Pisarczyk, Warszawa 2011, s. 211 i nast.

12 Por. M. Seweryński, Kryzys gospodarczy i prawo pracy, [w:] Prawo pracy. Refleksje i poszukiwania. Księga Jubileuszowa Profesora Jerzego Wratnego, Warszawa 2013, s. 30.

${ }^{13}$ Szerzej L. Florek, Ustawa i umowa w prawie pracy, Warszawa 2010, s. 181 i nast. 
czenie usług są w tym zakresie dalece niewystarczające. Znaczna ich część nie odnosi się zresztą do wykonywania pracy. Natomiast praktyka wykorzystuje przede wszystkim samą formę tych umów, a zwłaszcza ich nazwy, wypełniając je własną treścia, zgodnie z zasadą swobody umów (art. 3531 k.c.). Nierzadko też część postanowień takich umów ma na celu wykazanie, że strony łączy umowa cywilnoprawna, a nie umowa o pracę, chociaż ich przedmiotem jest świadczenie pracy zbliżone do pracowniczego. Podmiotom zatrudniającym, które wykorzystują i bardzo często nadużywają tych umów, chodzi o uzyskanie takiego świadczenia bez ochrony należnej pracownikom i zmniejszenie związanych z tym obciążeń wynikających z ubezpieczenia społecznego i prawa podatkowego.

Jednym ze sposobów ograniczenia tej praktyki jest przyznanie wykonawcom pracy na podstawie umów cywilnoprawnych niektórych uprawnień pracowniczych. Osoby te, podobnie jak pracownicy, są w pozycji słabszej w stosunku do podmiotów zlecających im pracę. Często jest ona słabsza na rynku pracy niż potencjalnych pracowników, ponieważ pracodawcy są w stanie narzucić im zatrudnienie niepracownicze. O ile jednak pojęcie pracownika jest ściśle zdefiniowane w kodeksie pracy, o tyle zakres osób objętych ochroną zbliżoną do pracowniczej musiałby być dopiero wyznaczony. Jest to tym trudniejsze, że powinny tu decydować kryteria ekonomiczne i społeczne, na przykład stałe uzyskiwanie określonego wynagrodzenia za pracę na rzecz jednego podmiotu zatrudniającego. Kryje się za tym potrzeba ochrony zbliżona do pracowniczej. Dotyczy to również tzw. samozatrudnienia. Sytuacja społeczna osób wykonujących takie zatrudnienie zbliża się do położenia pracowników. W samozatrudnieniu dochodzi bowiem do połączenia cech działalności gospodarczej i typowego zatrudnienia ${ }^{14}$. Odnosi się to zwłaszcza do zależności ekonomicznej od osób zlecających pracę (nazywanych także klientami ${ }^{15}$ ).

Wykonywanie pracy na podstawie umów cywilnoprawnych na określonych warunkach łączyłoby się na przykład z pisemną formą tych umów, pewną ochroną przed ich rozwiązaniem (np. okres wypowiedzenia), pewną ochroną wynagrodzenia (termin jego wypłaty), prawem do urlopu wypoczynkowego, a może także z pewnymi uprawnieniami związanymi z macierzyństwem (podobnie art. 462-475 projektu kodeksu pracy z 2007 r., o którym mowa poniżej). Przykładem takiego rozwiązania jest art. $304 \S 1$ k.p., zgodnie z którym pracodawca jest obowiązany zapewnić bezpieczne i higieniczne warunki pracy osobom fizycznym wykonującym

${ }_{14}$ M. Skąpski, Problem pojęcia i prawnej regulacji samozatrudnienia, [w:] Stosunki zatrudnienia w dwudziestoleciu społecznej gospodarki rynkowej. Księga pamiatkowa z okazji jubileuszu 40-lecia pracy naukowej Profesor Barbary Wagner, red. A. Sobczyk, Warszawa 2010, s. 90.

15 Ibidem. 
pracę na innej podstawie niż stosunek pracy. Zmniejszyłoby to różnicę pomiędzy umową o pracę a umowami cywilnoprawnymi, stanowiącą zachętę do zatrudniania na podstawie tych ostatnich.

Nie naruszałoby to dotychczasowej regulacji owych umów w kodeksie cywilnym, lecz przyznawałoby dodatkowe uprawnienia dla osób wykonujących pracę na podstawie wymienionych umów, na warunkach zbliżonych do pracowniczych. Obejmowałoby to również świadczenie pracy na podstawie tzw. samozatrudnienia. Przepisy kodeksu pracy w tym zakresie byłyby więc swego rodzaju „nakładką” na przepisy kodeksu cywilnego. Nie przekreśla to wyżej wspomnianej konieczności ujawniania i sankcjonowania zatrudnienia na podstawie pozornych umów cywilnoprawnych, jeżeli ma ono cechy, które kodeks pracy łączy z zatrudnieniem pracowniczym (stosunkiem pracy), w tym zwłaszcza jest wykonywane pod kierownictwem pracodawcy.

Przyznawanie uprawnień zbliżonych do pracowniczych wykonawcom pracy na innej podstawie niż stosunek pracy ma jednak swoje granice. Po pierwsze, nie może prowadzić do ucieczki pracodawców z jawnego rynku pracy w szarą strefę. Po wtóre, musi brać pod uwagę kondycję ekonomiczną małych i początkujących pracodawców, którzy z trudem mogą znosić dodatkowe obowiązki wobec zatrudnionych, tym bardziej że mogą się z tym łączyć zwiększone obowiązki ubezpieczeniowe i podatkowe.

Wykonawcom pracy należy również zagwarantować uprawnienia wynikające ze zbiorowego prawa pracy. Już obecnie art. $239 \S 2$ k.p. przewiduje, że układem zbiorowym mogą być objęte osoby świadczące pracę na innej podstawie niż stosunek pracy. Układ ten jest jednak zawierany przez związki zawodowe reprezentujące pracowników. Wykonawcom pracy należy więc zapewnić własną reprezentację, w tym szczególnie prawo tworzenia i przystępowania do związków zawodowych. Niezbędna jest jednak przy tym zmiana struktury związkowej, której punkt ciężkości spoczywa obecnie na zakładowych organizacjach związkowych. Częste zmiany pracy wykonywanej na podstawie umów cywilnoprawnych uzasadniają tworzenie przez nich struktur pozazakładowych, w tym zwłaszcza ponadzakładowych. Może się to przyczynić do wzmocnienia tych ostatnich, co jest pożądane z punktu widzenia rokowań zbiorowych, o czym mowa poniżej.

Przyszłość zbiorowego prawa pracy jest bardziej złożona niż prawa indywidualnego. Zbiorowe prawo pracy samo w sobie nie zapewnia prawidłowej regulacji zbiorowych stosunków pracy. O jego znaczeniu w dużym stopniu decyduje istnienie ${ }^{16} \mathrm{i}$ postawa partnerów społecznych. Prawo

${ }_{16}$ Zdanie R. Birka, Organizacje pracodawców w polskim prawie pracy, [w:] Ład społeczny w Polsce i Niemczech na tle jednoczacej się Europy. Księga pamiatkowa poświęcona Czesławowi Jackowiakowi, red. B. von Maydell i T. Zieliński, Warszawa 1999, s. 37, istnienie partnerów społecznych jest warunkiem funkcjonowania prawa pracy. 
może natomiast wspierać prawidłowy rozwój tych stosunków. Podstawowa sprawa dotyczy przedstawicielstwa pracowniczego. Z punktu widzenia potrzeby ochrony praw i interesów pracowników ich przedstawicielstwem powinny być przede wszystkim związki zawodowe. Wpływa na to wiele czynników, wśród których należy wymienić tradycję, ochronę jaką Konstytucja i prawo międzynarodowe udziela ich tworzeniu i działalności, wynikające z tego uprawnienia związków do prowadzenia negocjacji zbiorowych, sporów i strajków, co jest wspierane wielostopniową strukturą organizacyjną związków. Problemem wymagającym rozwiązania w przyszłości jest brak związków zawodowych u większości pracodawców. Zasadnicza część uprawnień związkowych przysługuje zakładowej organizacji związkowej, co dotyczy nie tylko indywidualnych spraw pracowniczych, ale zawierania zakładowego układu zbiorowego pracy czy prowadzenia zakładowego sporu zbiorowego. Możliwym rozwiązaniem prawnym jest przeniesienie zbiorowej ochrony interesów pracowników na wyższy szczebel, na przykład branżowy czy terytorialny. Ponadzakładowa organizacja związkowa mogłaby zawierać układy również z tym pracodawcami, u których nie ma związku zawodowego. Koresponduje to z postulatem M. Seweryńskiego, aby uprawnienia związkowe przyznać całemu związkowi, a nie tylko jego komórce zakładowej ${ }^{17}$. Służyłoby to także ujednoliceniu warunków pracy, a zwłaszcza płacy w danej grupie zawodowej, eliminując po części konkurowanie kosztami pracy. Innym możliwym sposobem wypełnienia braku zakładowego przedstawicielstwa pracowniczego jest poszerzenie roli rad pracowników ${ }^{18}$. Obawa związków zawodowych, że zatrzyma to proces uzwiązkowienia jest tylko częściowo słuszna, ponieważ liczba nowo powstających zakładowych organizacji związkowych jest niewielka. Oczywiście rady nie są w stanie przejąć tych spraw, które powszechnie są uważane za uprawnienia związkowe, jak negocjacje układowe, spory czy strajki. Dlatego też rady pracowników byłyby słabszym przedstawicielstwem pracowników niż związki zawodowe. Ewentualne zaś poszerzenie ich kompetencji mogłoby dotyczyć jedynie tych pracodawców, u których nie działają związki zawodowe. Nie ulega natomiast wątpliwości, że pozycja rady pracowników jest dużo silniejsza niż przedstawiciela pracowników wyłonionego w trybie przyjętym u danego pracodawcy (najczęściej w gruncie rzeczy nie ma

${ }_{17}$ M. Seweryński, Problemy legislacyjne zbiorowego prawa pracy, [w:] Prawo pracy RP w obliczu przemian, red. M. Matey-Tyrowicz, T. Zieliński, Warszawa 2006, s. 396.

${ }^{18}$ Już wiele lat temu uważano, że najbardziej pożądanym przedstawicielstwem pracowniczym byłyby rady zakładowe reprezentujące wszystkich zatrudnionych u danego pracodawcy, por. G. Goździewicz, Reprezentacja praw i interesów pracowniczych (ogólna charakterystyka), [w:] Reprezentacja praw i interesów pracowniczych, red. G. Goździewicz, Toruń 2001, s. 30. 
takiego trybu), który nie korzysta $\mathrm{z}$ ochrony ${ }^{19}$, a któremu prawo przyznaje szereg uprawnień. Rada pracowników jest bowiem ciałem demokratycznym, wyłanianym przez ogół pracowników danego pracodawcy w wyborach określonych ustawowo. Inaczej nie da się zrealizować słusznego postulatu, że ustawodawca powinien stymulować rozwój przedstawicielstwa zakładowego w różnych jego formach ${ }^{20}$.

7. Następną sprawą która wymaga rozwiązania w przyszłości, są układy zbiorowe pracy. Zawiera się je przede wszystkim na szczeblu zakładu pracy, a ich liczba maleje ${ }^{21}$. Można wręcz mówić o atrofii ponadzakładowych rokowań zbiorowych ${ }^{22}$. Stanowi to regres w stosunku do okresu międzywojennego, gdy same przedsiębiorstwa dążyły do tego, aby żadne $\mathrm{z}$ nich nie pozostawało poza układem, a tym samym nie konkurowało z pozostałymi, "robiąc oszczędności na płacach i innych uprawnieniach pracowniczych" ${ }^{23}$. Również obecnie podkreśla się, że układ ponadzakładowy ogranicza konkurencję kosztami pracy. Brak układów ponadzakładowych uniemożliwia także generalizację układów, to jest rozciąganie ich postanowień na pracodawców nie objętych żadnym układem.

Słabość praktyki układowej na szczeblu ponadzakładowym jest spowodowana między innymi całkowitym brakiem organizacji pracodawców upoważnionych do zawarcia takich układów. Jest to zarazem wynikiem postawy organizacji związkowych. Zdając sobie sprawę ze swojej ograniczonej roli, związki wolą wywierać wpływ na ustawodawstwo państwowe niż same prowadzić rokowania zbiorowe. Z punktu widzenia państwa jest to sytuacja niekorzystna, ponieważ powinno ono dążyć do przekazania partnerom społecznym części swoich uprawnień w zakresie ochrony pracowników.

Bardzo słabe wykorzystanie układów na szczeblu ponadzakładowym łączy się też ze słabo rozwiniętymi strukturami ponadzakładowymi związków zawodowych i pracodawców, które mogłyby zawierać układy ponadzakładowe (dominujące w świecie). Do tego dochodzi niechęć pra-

19 Przyznanie mu takiej ochrony stanowi warunek „rzeczywistego dialogu równorzędnych partnerów społecznych", Ł. Pisarczyk, Udział partnerów społecznych w kształtowaniu wynagrodzenia za prace, [w:] Stosunki zatrudnienia w dwudziestoleciu społecznej gospodarki..., s. 153.

${ }^{20} \mathrm{~J}$. Stelina, Zwiazki zawodowe a pozazwiąkowe przedstawicielstwo pracowników w zakładzie pracy, [w:] Związkowe przedstawicielstwo pracowników zakładu pracy, red. Z. Hajn, Warszawa 2012, s. 187.

${ }^{21}$ Według danych Państwowej Inspekcji Pracy w ostatnich latach rocznie rejestruje się około 100 zakładowych układów zbiorowych, przy czym jest to tendencja malejąca, por. Sprawozdanie z działalności Państwowej Inspekcji Pracy w 2013 r., s. 27.

${ }^{22}$ Por. Z. Hajn, Ustawowy model organizacji polskiego ruchu zwiazkowego i jego wptyw na zbiorowe stosunki pracy, [w:] Prawo pracy a wyzwania XXI wieku..., s. 439.

${ }^{23}$ Por. M. Święcicki, Prawo pracy, Warszawa 1968, s. 93. 
codawców do zawierania takich układów, zwłaszcza jeżeli miałyby one objąć zakłady pozbawione związku zawodowego. Dlatego też organizacje pracodawców, bez względu na podstawę prawną ich działania, z reguły nie mają upoważnienia do zawierania układów. Przemawia to za usunięciem ograniczenia zdolności układowej pracodawców na szczeblu ponadzakładowym tylko do ich organizacji (por. art. $241^{14} \S 1$ pkt 2 k.p.). Jeżeli istnieje określona struktura związkowa i pracodawcza (w tym także nawet nieformalna grupa pracodawców), która chce zawrzeć taki układ, to prawo nie powinno tego utrudniać. Najważniejsze jest, aby dana organizacja pracodawców była upoważniona i skłonna do zawarcia go w imieniu reprezentowanych przez siebie pracodawców, a związki zawodowe reprezentowały objętych nim pracowników.

\section{Bibliografia}

Birk R., Organizacje pracodawców w polskim prawie pracy, [w:] Ład społeczny w Polsce i Niemczech na tle jednoczacej się Europy. Księga pamiątkowa poświęcona Czesławowi Jackowiakowi, red. B. von Maydell i T. Zieliński, Warszawa 1999.

Florek L., Ustawa i umowa w prawie pracy, Warszawa 2010.

Goździewicz G., Reprezentacja praw i interesów pracowniczych (ogólna charakterystyka), [w:] Reprezentacja praw i interesów pracowniczych, red. G. Goździewicz, Toruń 2001.

Hajn Z., Ustawowy model organizacji polskiego ruchu zwiazkowego i jego wptyw na zbiorowe stosunki pracy, [w:] Prawo pracy a wyzwania XXI wieku. Ksiegga jubileuszowa Profesora Tadeusza Zielińskiego, red. M. Matey-Tyrowicz, L. Nawacki, B. Wagner, Warszawa 2002.

Hanau P., Adomeit K., Arbeitsrecht, München 2005.

Jończyk J., Prawo pracy, Warszawa 1995.

Kijowski A., Zakres swobody pracodawcy w korzystaniu z zatrudnienia cywilnoprawnego, [w:] Prawo pracy a wyzwania XXI wieku. Ksiega jubileuszowa Profesora Tadeusza Zielińskiego, red. M. Matey-Tyrowicz, L. Nawacki, B. Wagner, Warszawa 2002.

Liszcz T., Swoboda umów w prawie pracy, [w:] Wolność i sprawiedliwość w zatrudnieniu. Księga Pamiątkowa poświęcona Prezydentowi Rzeczypospolitej Polskiej Profesorowi Lechowi Kaczyńskiemu, red. M. Seweryński, J. Stelina, Gdańsk 2012.

Pisarczyk Ł., "Uelastycznienie” czasu pracy jako element przemian stosunku pracy, [w:] Z zagadnień prawa pracy i prawa socjalnego. Księga Jubileuszowa Profesora Herberta Szurgacza, Warszawa 2011.

Pisarczyk Ł., Udział partnerów społecznych w kształtowaniu wynagrodzenia za pracę, [w:] Stosunki zatrudnienia w dwudziestoleciu społecznej gospodarki rynkowej. Ksiega pamiątkowa z okazji jubileuszu 40-lecia pracy naukowej Profesor Barbary Wagner, red. A. Sobczyk, Warszawa 2010.

Rycak M., Wptyw koncepcji flexicurity na przemiany stosunku pracy, [w:] Wspótczesne problemy prawa pracy i ubezpieczeń społecznych, red. L. Florek, Ł. Pisarczyk, Warszawa 2011.

Seweryński M., Kryzys gospodarczy i prawo pracy, [w:] Prawo pracy. Refleksje i poszukiwania. Ksiega Jubileuszowa Profesora Jerzego Wratnego, Warszawa 2013.

Seweryński M., Problemy legislacyjne zbiorowego prawa pracy, [w:] Prawo pracy RP w obliczu przemian, red. M. Matey-Tyrowicz, T. Zieliński, Warszawa 2006, 
Seweryński M., Uwagi o efektywności prawa pracy, [w:] Księga Pamiątkowa w piąta rocznice śmierci Profesora Andrzeja Kijowskiego, red. Z. Niedbała, Warszawa 2010.

Skąpski M., Problem pojęcia i prawnej regulacji samozatrudnienia, [w:] Stosunki zatrudnienia $w$ dwudziestoleciu społecznej gospodarki rynkowej, Ksiegga pamiątkowa z okazji jubileuszu 40-lecia pracy naukowej Profesor Barbary Wagner, red. A. Sobczyk, Warszawa 2010.

Stelina J., Zwiąki zawodowe a pozazwiazkowe przedstawicielstwo pracowników w zakładzie pracy, [w:] Zwiazkowe przedstawicielstwo pracowników zakładu pracy, red. Z. Hajn, Warszawa 2012.

Supiot A. (red.), Beyond Employment. Changes in Work and the Future of Labour Law in Europe, Oxford University Press, Oxford 2001.

Święcicki M., Prawo pracy, Warszawa 1968.

\section{Key Issues for the Future of Labour Law}

\section{Summary}

Key issues for the future of labour law are among other things the preservation of the employment relationship as a major base of employment, restrictions on the freedom of contracts, the enforcement of the employment regulations, making labour law more flexible, development of atypical forms of employment and the protection of other work, including in particular employment on the civil law basis. The latter is connected with granting certain employee rights to performers working on the basis of civil law contracts. In the field of collective labour law in Poland the problem of non-union employee representation should be settled. There also significant increase of the role of collective agreements is needed.

The lack of solutions to these issues in the future (especially the consent to moving away from the employment relationship or keeping a substantial difference between the employment relationship and employment on the basis of civil law contracts) threatens with reduction in its importance and hence a significant reduction in the protection of employees. While no appropriate employees representation or collective agreements must mean retardation of collective labour law, what in the long run is detrimental to the economy. 